\title{
Roll enriched with Nile tilapia meal: sensory, nutritional, technological and microbiological characteristics
}

\author{
Ana Paula Sartorio CHAMBÓ ${ }^{1}$, Maria Luiza Rodrigues de SOUZA ${ }^{2 *}$, Edna Regina Netto de OLIVEIRA ${ }^{3}$, \\ Jane Martha Graton MIKCHA ${ }^{3}$, Diego Rodrigues MARQUES ${ }^{4}$, Fabiana Carla MAISTROVICZ ${ }^{5}$, \\ Jesuí Vergilio VISENTAINER ${ }^{5}$, Elenice Souza dos Reis GOES 6
}

\begin{abstract}
This study evaluated the chemical composition, fatty acid profile, technological quality, sensory profile and microbiological characteristics of rolls with inclusion of 0, 5, 10 and 15\% meal prepared with tilapia carcasses. Moisture and carbohydrate content were linearly reduced $(\mathrm{P}<0.05)$ with increasing inclusion of tilapia meal, but a linear increase $(\mathrm{P}<0.0001)$ was observed in protein $(9.91$ to $14.30 \%)$ and ash (1.74 to $4.65 \%)$ content. Lipids and calorific value of the rolls were not affected $(\mathrm{P}>0.05)$ by inclusion levels, but $15 \%$ tilapia meal resulted in greater amount of polyunsaturated fatty acids $(4.63 \%)$ in relation to $0 \%$ inclusion $(4.46 \%)$. There was a linear increase $(\mathrm{P}<0.0001)$ in the firmness of the breads $(3.65$ to $13.17 \mathrm{~N})$ and a linear decrease $(\mathrm{P}<0.001)$ in volume and specific volume. Sensory attributes showed a negative linear effect $(\mathrm{P}<0.01)$, with acceptance rates ranging from $85.24 \%$ ( $0 \%$ inclusion) to $70.57 \%$ ( $15 \%$ inclusion). It can be concluded that the inclusion of 5 to $15 \%$ tilapia meal in roll is effective to increase the protein, mineral matter, polyunsaturated fatty acids and the firmness of the roll, in addition to reducing carbohydrates and volume. Considering the reduction in sensory acceptance, it is recommended to use up to $10 \%$ tilapia meal in rolls.
\end{abstract}

Keywords: Oreochromis niloticus; waste reuse; fish protein concentrate.

Practical Application: Rools with meal prepared with tilapia carcasses have high nutritional value and great sensory profile.

\section{Introduction}

The eating habits has undergone diverse changes resulting from social, environmental and technological factors, replacing the consumption of natural foods with industrialized products, consequently reducing the intake of some essential nutrients, such as vitamins, minerals and fiber, and increasing the consumption of carbohydrates and fats. These changes have provided great business opportunities to the food industry, which has shown particular interest in improving the nutritional value of processed products (Collar, 2015), giving rise to fortified and enriched products.

Roll is present in $85 \%$ of the bread market in Brazil, the preferred product in all social levels (Carr et al., 2006). Nutritionally, this bread contains low protein content, high percentage of carbohydrates and small amounts of dietary fiber (Dhinda et al., 2012), and vitamins and minerals are also present in minor proportions (Adeleke \& Odedeji, 2010). The inclusion of ingredients or partial replacement of wheat flour with other flours, of vegetable or animal origin, can increase the nutritional value of the bread.

Several techniques have been used to improve the nutritional composition of foodstuffs, for example, the partial or total replacement of some traditional ingredients with alternative products and developing products that add nutritional and technological quality associated with a low cost. Therefore, the fortification of these products can be made by the addition of cereals (e.g. barley, spelt, rye, einkorn, millet, oat, sorghum) or pseudocereals (e.g. quinoa, amaranth, buckwheat) (Angioloni \& Collar, 2011) and food sources of animal protein, such as fish (Centenaro et al., 2007).

Fish and fish products are sources of protein with high biological value and excellent balance of essential amino acids (Centenaro et al., 2007), they are source of vitamins, minerals and essential fatty acids (Tacon \& Metian, 2013; Cho \& Kim, 2011) and, therefore, capable of increasing the nutritional value of the diet and foods receiving their supplementation.

\footnotetext{
Received 08 May, 2017

Accepted 06 Aug., 2017

${ }^{1}$ Post Graduate in Animal Science, Universidade Estadual de Maringá - UEM, Maringá, PR, Brazil

${ }^{2}$ Department of Animal Science, Universidade Estadual de Maringá - UEM, Maringá, PR, Brazil

${ }^{3}$ Health Sciences Center, Universidade Estadual de Maringá - UEM, Maringá, PR, Brazil

${ }^{4}$ Post Graduate in Food Science, Universidade Estadual de Maringá - UEM, Maringá, PR, Brazil

${ }^{5}$ Department of Chemistry, Universidade Estadual de Maringá - UEM, Maringá, PR, Brazil

${ }^{6}$ Faculty of Agricultural Sciences, Universidade Federal da Grande Dourados - UFGD, Dourados, MS, Brazil

*Corresponding author: mlrsouza@uem.br
} 
The goal of the present study was to evaluate the chemical composition, technical quality, sensory and microbiological profile of rolls added with meal prepared with Nile tilapia carcasses.

\section{Material and methods}

The bread making process was based on that described by El-Dash et al. (1994). The production of standard roll used the following proportion of ingredients: $100 \%$ special wheat flour for roll; $58 \%$ water; $1 \%$ yeast. The production of fortified rolls used three levels of inclusion of fish meal (5\%,10\% and 15\%) into the dough, replacing wheat flour.

Fish meal was produced from carcasses (spine with ribs and meat attached to bones after filleting) of Nile tilapia (Oreochromis niloticus) without head and fins. These were washed, weighed, added with BHT $(0.01 \%)$ and cooked for 60 minutes. After, the material was drained and pressed in a hydraulic press (10 tons) to remove excess natural fat and the press cake was ground in an electric meat grinder (CAF). The obtained mass was evenly distributed on trays and dried in a forced ventilation oven at $60^{\circ} \mathrm{C}$ for 24 hours. The dehydration product was ground in a knife mill, vacuum packed and frozen at $-18{ }^{\circ} \mathrm{C}$ for later inclusion in the dough of rolls.

For production of rolls, ingredients were mixed in a spiral kneader (AES-25-Braesi) for 13 minutes (6 minutes at 90rpm, and 7 minutes at 180rpm). They were then divided into $60 \mathrm{~g}$ portions and rounded up. After resting for 20 minutes, balls were shaped with the aid of table moulder (MB35- Braesi), poured into molds and fermented for 105 minutes in a fermentation chamber for 24 trays. Breads were baked in a Tedesco gas oven (FTT240) at $180^{\circ} \mathrm{C}$ for 20 minutes with forced air circulation and without steam injection. After cold, rolls were packed in plastic bags.

Microbiological analyses included the most probable number (MPN) of coliforms at $35^{\circ} \mathrm{C} /$ gram and $45^{\circ} \mathrm{C} /$ gram, Staphylococcus coagulase-positive count in CFU/gram and Salmonella spp, according to Americam Pubblic Health Association (1992).

Analyses for moisture, ash and proteins were carried out according to the methodology of Association of Official Analytical Chemists (2005) for samples of breads and tilapia meal. For lipids, we used the methodology of Bligh \& Dyer (1959). Total carbohydrates were calculated by the difference in the sum of percentages of the compounds analyzed by $100 \%$. The caloric value was calculated for $100 \mathrm{~g}$ sample and for a serving of the product. Analyses were performed in triplicate for bread and tilapia meal, but for bread, five rolls were randomly selected per treatment.

To determine the fatty acid profile, total lipids were transesterified in accordance with the ISO method. Fatty acid methyl esters were separated on a gas chromatograph (Varian 3380) equipped with a flame ionization detector and a fused silica capillary column CP-7420 Select FAME (100 m long, $0.25 \mathrm{~mm}$ internal diameter, $0.25 \mu \mathrm{m}$ cyanopropyl). The $\mathrm{H}_{2}$ flow (carrier gas) was $1.0 \mathrm{~mL} / \mathrm{min}$, with $30 \mathrm{~mL} / \mathrm{min}_{2}$ (makeup); 30 and $300 \mathrm{~mL} / \mathrm{min}$ for $\mathrm{H}_{2}$ and synthetic air for the flame detector. The injected volume was $0.2 \mu \mathrm{L}$, using a 1:80 split ratio, injector and detector temperatures were 220 and $240{ }^{\circ} \mathrm{C}$, respectively, while the column temperature was $165^{\circ} \mathrm{C}$ during $18 \mathrm{~min}$ and raised to $235^{\circ} \mathrm{C}$ at a rate of $4^{\circ} \mathrm{C} / \mathrm{min}$, held for $24.5 \mathrm{~min}$.

The identification of fatty acids were made using the following criteria: comparison of retention times of Sigma standard methyl esters (USA) with the samples and comparison of ECL (Equivalent Chain Length) values of methyl esters of samples with values found in Strànsky et al. (1997).

Technological characteristics of roll were evaluated about one hour after baking, determining the specific volume $\left(\mathrm{mL} \cdot \mathrm{g}^{-1}\right)$ of the rolls obtained by the ratio between the apparent volume $(\mathrm{mL})$ by the millet seed displacement, and weight $(\mathrm{g})$ of bread (El-Dash et al., 1982). For pH, 10 grams of each sample was homogenized with $90 \mathrm{~mL}$ distilled water and the $\mathrm{pH}$ of this was measured using a potentiometer (0400, Quimis, São Paulo, Brazil), previously calibrated and operated according to the manufacturer's instructions.

For analysis of the bread texture profile, we evaluated firmness $(\mathrm{N})$ and maximum compression $(\mathrm{g})$ with the aid of a texturometer (TA-XT2i, Stable Micro Systems, Surrey, UK), equipped with cylindrical compression probe (TA -11), $35 \mathrm{~mm}$ in diameter. We used $2.0 \mathrm{~mm} / \mathrm{s}$ pre-test speed and $5.0 \mathrm{~mm} / \mathrm{s}$ test and post-test speed, $20 \mathrm{~mm}$ distance, $20 \mathrm{~g}$ trigger type and $5 \mathrm{~s}$ time between compressions. For analysis of these parameters, the ends of the roll were removed, resulting in a cylinder with approximately $6.0 \mathrm{~cm}$ long (Carr \& Tadini, 2003).

Values of lightness $\left(\mathrm{L}^{*}\right)$ were measured using a colorimeter (MINOLTA CR-10, Minolta Camera Co., Osaka, Japan), at an angle of $90^{\circ}$, at room temperature, wherein $\mathrm{L}^{*}$ defines the lightness ( $\mathrm{L}^{\star}=0$ black and $\mathrm{L}^{\star}=100$ white), $\mathrm{a}^{\star}$ (red-green component) and $\mathrm{b}^{\star}$ (yellow-blue component).

Sensory analysis was performed with 50 untrained panelists, randomly selected and without any knowledge of the composition of the samples. Methods of sensory analysis was approved by the Comitê Permanente de Ética em Pesquisa com Seres Humanos (COPEP) of the Universidade Estadual de Maringá, Maringá PR Brazil (Protocol 458.151/2013-COPEP). We evaluated the attributes surface color, crumb color, appearance, aroma, texture, flavor and overall impression, using a 9-point hedonic scale, anchored between minimum and maximum: dislike extremely (1) to like extremely (9) (Dutcosky, 2011). With these data, we calculated the Acceptability Index (AI) using Formula 1 (Dutcosky, 2011):

$I A \%=\frac{\text { averagescore }}{\max \text { imum score }} \times 100$

In addition, the panelists were asked about the purchase intent with a 5 -point hedonic scale ranging from 1 (definitely will not buy) and 5 (definitely will buy), according to Dutcosky (2011).

For statistical analysis, we used the methodology of generalized linear models (GENMOD procedure) considering the distribution of variables as gamma with inverse link function, using the Statistical Analysis System (SAS, SAS Inst. Inc. Cary, NC, USA). It was considered the effect of treatment and panelists, testing the inclusion levels from regression analysis. A regression analysis at 5\% significance level tested the other 
parameters. Fatty acid profile, $\mathrm{pH}$ and microbiological analysis were descriptively analyzed.

\section{Results and discussion}

The microbiological analysis of roll with different levels of inclusion of tilapia meal indicated a low number $(<3$ Most Probable Number/gram) of coliforms at $35^{\circ} \mathrm{C}$ and $45^{\circ} \mathrm{C},<10^{2}$ Colony-Forming Units/gram of Sthapylococcus coagulase positive, as well as absence of Salmonella sp., showing that the rolls were fit for human consumption and within the microbiological standards required by the Brazilian legislation (Brasil, 2001).

The proximate composition of roll showed a significant effect $(\mathrm{P}<0.01)$ between treatments for moisture, protein, ash and carbohydrates (Table 1). The contents of moisture and carbohydrates decreased linearly $(\mathrm{P}<0.05)$ as increased inclusion of tilapia meal $\left(y=-0.20118 x+36.04926, R^{2}=0.58\right.$ for moisture and $y=-0.28884 x+50.90774, R^{2}=0.90$ for carbohydrates).

The decrease in moisture content may be related to moisture in the tilapia meal, which was $1.78 \%$. Wheat flour contains average of $14.2 \%$ moisture (Van Steertegem et al., 2013), and when replacing the flour with tilapia meal (1.78\% moisture), there was a reduction in the moisture content of the roll. Moisture is one of the most sensitive quality attributes, significantly interfering with deterioration after a few days of storage (Besbes et al., 2014), thus the reduction in moisture can be important to increase the shelf life of the product.

There was a linear increase $(\mathrm{P}<0.0001)$ for crude protein $\left(\mathrm{y}=0.28142 \mathrm{x}+10.28392 \mathrm{R}^{2}=0.94\right)$ and ash $(\mathrm{y}=0.192386 \mathrm{x}+$ $1.876885 \mathrm{R}^{2}=0.97$ ), with $0 \%$ inclusion resulted in $9.91 \%$ protein and $1.74 \%$ ash, and $15 \%$ inclusion resulted in $14.30 \%$ and $4.65 \%$ of protein and ash, respectively. This increase was due to the protein and ash content present in Nile tilapia meal (51.13\% crude protein and $37.66 \%$ ash).

Centenaro et al. (2007) developed bread with inclusion of wet and dried washed pulp of Prionotus punctatus and obtained average values of $11.0 \%$ crude protein for bread without inclusion of pulp, $15.5 \%$ with $3 \%$ dry pulp, $17.1 \%$ with $5 \%$ dry pulp and $17.5 \%$ with $50 \%$ wet pulp.

In breads added with $0,5,10,15$ and $20 \%$ tilapia protein concentrate, we can observe a linear increase in crude protein $(9.08$, $10.59,12.14,16.45$ and $18.01 \%$, respectively) and a decrease in carbohydrates $(60.20,58.00,57.86,48.91$ and $49.05 \%$ respectively)
(Adeleke \& Odedeji, 2010), similar to the effect observed in this study for these variables. These results demonstrate that inclusion of fishmeal is effective to enrich bread with protein and other products such as pasta (Goes et al., 2016); khitchri (Hussain et al., 2007), snacks (Justen et al., 2016), salt biscuits (Ibrahim, 2009), among other products.

The reduction in carbohydrate content with the addition of fishmeal to roll is due to the reduced amount of wheat flour. Considering that wheat flour represented the largest source of carbohydrates in roll, this decrease was possibly because the inclusion of tilapia meal was over the total wheat flour; thus, the greater the inclusion, the lower the amount of wheat flour, which influenced directly on the roll carbohydrate content. Furthermore, carbohydrates values found in rolls of this study are lower than those obtained by Centenaro et al. (2007), who obtained carbohydrates from 77.6 to $83.5 \%$.

The increased ash content of the roll (from 1.74 to $4.65 \%$ for 0 to $15 \%$ inclusion of fishmeal, respectively) can be considered beneficial, since aquatic animal food products are a richer source of most essential minerals and trace elements than most terrestrial meats (Tacon \& Metian, 2013). In pasta with different levels of inclusion $(0,10,20$ and 30\%) Nile tilapia meal, Goes et al. (2016) observed a linear increase in the concentrations of calcium, phosphorus, magnesium, sodium and zinc, showing that the inclusion of tilapia meal can improve the mineral profile of the product.

Lipid content and caloric value of rolls were not affected ( $P>0.05)$ by different levels of inclusion of Nile tilapia meal, averaging $1.00 \%$ for lipids and $253.58 \mathrm{kcal} / 100 \mathrm{~g}$ for caloric value. However, the Nile tilapia meal used had $5.82 \%$ fat, and despite the lack of difference in lipid content, it can be verified changes in the fatty acid profile of the rolls, according to the different inclusion levels of fishmeal.

The fatty acid profile (Table 2 ) detected the predominance of oleic (18:1n-9c), palmitic (16:0) and stearic (18:0) acids in all rolls. This is due to tilapia meal composition, because in meals prepared with heads or spine of tilapia, there was a predominance of palmitic (16:0), oleic (18:1n-9) and linoleic (18:2n-6) acids (Souza et al., 2008).

The inclusion of $15 \%$ Nile tilapia meal into roll resulted in higher amounts of polyunsaturated fatty acids (4.63\%), compared to roll without inclusion (4.46\%). Moreover, the inclusion of 5, 10 or $15 \%$ Nile tilapia meal promoted an increase

Table 1. Proximate composition and caloric value of rolls with different levels of inclusion of Nile tilapia meal.

\begin{tabular}{|c|c|c|c|c|c|}
\hline & \multicolumn{4}{|c|}{ Inclusion levels } & \multirow{2}{*}{$\mathrm{P}$ value } \\
\hline & $0 \%$ & $5 \%$ & $10 \%$ & $15 \%$ & \\
\hline Moisture & $37.00 \pm 0.18$ & $33.69 \pm 0.69$ & $33.89 \pm 0.02$ & $33.58 \pm 0.09$ & $0.0271^{\mathrm{a}}$ \\
\hline Crude protein & $9.91 \pm 0.25$ & $12.24 \pm 0.04$ & $13.13 \pm 0.08$ & $14.30 \pm 0.19$ & $<0.0001^{\mathrm{b}}$ \\
\hline Lipids & $0.82 \pm 0.03$ & $0.95 \pm 0.01$ & $1.26 \pm 0.03$ & $0.99 \pm 0.01$ & 0.1431 \\
\hline Ash & $1.74 \pm 0.04$ & $3.01 \pm 0.18$ & $3.88 \pm 0.11$ & $4.65 \pm 0.13$ & $<0.0001^{\mathrm{c}}$ \\
\hline Carbohydrates & $50.53 \pm 0.40$ & $50.11 \pm 0.54$ & $47.84 \pm 0.17$ & $46.48 \pm 0.23$ & $0.0003^{\mathrm{d}}$ \\
\hline Calorie $(\mathrm{kcal} / 100 \mathrm{~g})$ & $249.14 \pm 0.53$ & $257.97 \pm 2.08$ & $255.21 \pm 0.39$ & $251.99 \pm 0.14$ & 0.6599 \\
\hline
\end{tabular}


in the content of omega- 3 fatty acids $(0.46,0.49$ and $0.49 \%$, respectively) compared to the control roll (0.44\%). For omega- 6 fatty acids, the levels of 10 and $15 \%$ inclusion of meal had higher values (3.90 and 3.96\%) in comparison with roll without Nile tilapia meal (3.84\%). The highest amount of omega- 6 in the rolls is related to the greater presence of this series of fatty acids in Nile tilapia, as pointed out by Bonafé et al. (2013).

The highest content of polyunsaturated fatty acids in roll added with tilapia meal demonstrates the improvement in the nutritional profile of roll, as these fatty acids, especially omega-3, are associated with many health benefits, mainly by reducing

Table 2. Fatty acid profile (\%) of rolls with different levels of inclusion of Nile tilapia meal.

\begin{tabular}{crrrr}
\hline \multirow{2}{*}{ Fatty acid (\%) } & \multicolumn{4}{c}{ Inclusion levels (\%) } \\
\cline { 2 - 5 } $14: 0$ & 0 & \multicolumn{1}{c}{5} & \multicolumn{1}{c}{10} & \multicolumn{1}{c}{15} \\
\hline $14: 1$ & 1.00 & 1.02 & 1.09 & 1.02 \\
$15: 0$ & 0.46 & 0.44 & 0.45 & 0.45 \\
$16: 0$ & 25.74 & 25.83 & 25.83 & 25.70 \\
$16: 1 \mathrm{n}-9$ & 0.29 & 0.21 & 0.23 & 0.29 \\
$16: 1 \mathrm{n}-7$ & 3.01 & 2.94 & 3.18 & 3.10 \\
$16: 1 \mathrm{n}-5$ & 0.56 & 0.41 & 0.53 & 0.58 \\
$17: 0$ & 1.08 & 1.07 & 1.07 & 1.08 \\
$18: 0$ & 15.61 & 15.54 & 15.03 & 15.70 \\
$18: 1 \mathrm{n}-9 \mathrm{c}$ & 42.62 & 43.50 & 43.24 & 42.12 \\
$18: 1 \mathrm{n}-7$ & 1.36 & 1.04 & 1.10 & 1.53 \\
$18: 2 \mathrm{n}-6 \mathrm{c}$ & 3.56 & 3.56 & 3.51 & 3.60 \\
$18: 3 \mathrm{n}-6$ & 0.15 & 0.15 & 0.15 & 0.16 \\
$18: 3 \mathrm{n}-3$ & 0.44 & 0.46 & 0.49 & 0.46 \\
$20: 0$ & 0.82 & 0.84 & 0.88 & 0.85 \\
$20: 1 \mathrm{n}-9$ & 0.37 & 0.39 & 0.37 & 0.39 \\
$21: 0$ & 0.13 & 0.14 & 0.13 & 0.14 \\
$20: 3 \mathrm{n}-6$ & $\mathrm{ND}$ & $\mathrm{ND}$ & 0.06 & 0.05 \\
$20: 4 \mathrm{n}-6$ & 0.13 & $\mathrm{ND}$ & 0.18 & 0.14 \\
$20: 3 \mathrm{n}-3$ & $\mathrm{ND}$ & $\mathrm{ND}$ & $\mathrm{ND}$ & 0.03 \\
$24: 1 \mathrm{n}-9$ & 0.17 & $\mathrm{ND}$ & $\mathrm{ND}$ & 0.18 \\
Sum of monounsaturated fatty acids & 63.62 & 64.02 & 63.67 & 63.37 \\
num of polyunsaturated fatty acids & 4.46 & 4.17 & 4.39 & 4.63 \\
$\mathrm{n}-6$ sum & 0.44 & 0.46 & 0.49 & 0.49 \\
Sum of saturated fatty acids & 3.84 & 3.70 & 3.90 & 3.96 \\
\hline ND Non-detected. & & & & \\
& & & &
\end{tabular}

the incidence of cardiovascular diseases (Walker et al., 2013; Marik \& Varon, 2009).

As for the texture of roll (Table 3), the weight and the compression were not affected $(\mathrm{P}>0.05)$ by different levels of inclusion of tilapia meal, with a mean weight of $49.82 \mathrm{~g}$ and mean compressive deformation of $961.90 \mathrm{Kgf}$. These values are within the standard range, since a typical roll in Brazil has $50 \mathrm{~g}$ final weight, $12.5 \mathrm{~cm}$ long and $5.5 \mathrm{~cm}$ in diameter (Carr et al., 2006).

Additionally, there was a linear increase $(\mathrm{P}<0.0001)$ in the firmness of rolls, ranging from $3.65 \mathrm{~N}(0 \%$ inclusion $)$ to $13.17 \mathrm{~N}$ ( $15 \%$ inclusion), according to equation $y=0.6860 x+2.069$ $\left(R^{2}=0.74\right)$. This indicates that, as fishmeal was added into the dough, there was an increase in dough stiffness and hardness, resulting in a more compacted mass (Figure 1). The increase in firmness may be due to the decrease in the amount of gluten as a function of the substitution of part of the wheat flour for fishmeal. According to Esteller et al. (2005), the addition of 3 and 6\% of freeze-dried gluten lowered the firmness of hamburger buns.

For volume and specific volume (Table 3), it was observed that with increasing inclusion of fishmeal, there was a linear decrease in these parameters $(\mathrm{P}<0.001)$. The roll volume decreased from $245.00 \mathrm{~mL}$ ( $0 \%$ inclusion) to $131.33 \mathrm{~mL}$ with $15 \%$ inclusion of fishmeal $\left(y=-7.4467 x+247.7667 ; R^{2}=0.92\right)$. The specific volume showed a similar behavior, ranging from $4.53 \mathrm{~mL} \mathrm{~g}^{-1}$ with $0 \%$ inclusion to $2.33 \mathrm{~mL} \mathrm{~g}^{-1}$ with $15 \%$ inclusion $(\mathrm{y}=-0.1438 \mathrm{x}+$ $4.566 \mathrm{R}^{2}=0.99$ ), which represents a reduction of almost $50 \%$ of its specific volume. In this way, although the weight of roll has not changed, the specific volume varied significantly between treatments, with a linear reduction with increasing levels of inclusion of Nile tilapia meal. From a technological perspective, the reduced specific volume of rolls is a disadvantage, because it changes the conventional characteristics of the dough and can affect their acceptance.

The decrease in specific volume of roll was because the roll volume is given by entrapment of carbon dioxide, from the fermentation, by the gluten network (Verheyen et al., 2015). Therefore, replacing part of the wheat flour, which is the main source of sugars in the formulation, with fishmeal, a non-fermentable product, in addition to reducing carbon dioxide production tends to reduce the strength of the gluten network, resulting in a lesser entrapment of gas and, consequently, a smaller volume.

This same technology characteristic was also observed by Centenaro et al. (2007), where the specific volume of breads diminished gradually with the addition of 3 and $5 \%$ fish dried

Table 3. Analysis of texture, volume and $\mathrm{pH}$ of rolls with different levels of inclusion of Nile tilapia meal.

\begin{tabular}{|c|c|c|c|c|c|}
\hline & \multicolumn{4}{|c|}{ Inclusion levels } & \multirow{2}{*}{$\mathrm{P}$ value } \\
\hline & $0 \%$ & $5 \%$ & $10 \%$ & $15 \%$ & \\
\hline Weight (g) & 49.301 .22 & $50.50 \pm 0.50$ & $49.50 \pm 0.50$ & $50.00 \pm 0.32$ & 0.7017 \\
\hline Firmness (N) & $3.65 \pm 0.13$ & $5.16 \pm 0.47$ & $7.68 \pm 0.31$ & $13.17 \pm 0.59$ & $<0.0001^{\mathrm{a}}$ \\
\hline Compression (Kgf) & $826.90 \pm 78.51$ & $1078.00 \pm 93.77$ & $1045.70 \pm 104.53$ & $897.00 \pm 94.57$ & 0.3350 \\
\hline Volume $(\mathrm{ml})$ & $245.00 \pm 2.89$ & $211.33 \pm 9.26$ & $180.00 \pm 10.78$ & $131.33 \pm 5.92$ & $<0.0001^{\mathrm{b}}$ \\
\hline Specific volume $\left(\mathrm{ml} \cdot \mathrm{g}^{-1}\right)$ & $4.53 \pm 0.09$ & $3.84 \pm 0.30$ & $3.25 \pm 0.33$ & $2.33 \pm 0.18$ & $<0.001^{\mathrm{c}}$ \\
\hline $\mathrm{pH}$ & 6.04 & 5.89 & 5.94 & 5.89 & - \\
\hline
\end{tabular}

${ }^{a} y=0.686033 x+2.069833 R^{2}=0.74 ;{ }^{b} y=-7.4467 x+247.7667 R^{2}=0.92 ;{ }^{c} y=-0.1438 x+4.566 R^{2}=0.99$. Values presented as mean \pm standard error of the mean. 
pulp (4.08 and $\left.3.32 \mathrm{~mL} \mathrm{~g}^{-1}\right)$ and 50\% fish wet pulp $\left(2.29 \mathrm{~mL} \mathrm{~g}^{-1}\right)$. This suggests that when working with inclusion of fishmeal into bakery products, its inclusion should be done with caution to not harm the technological characteristics of the product. Sidwell \& Hammerle (1970) concluded that an addition of $10 \%$ or more of fish protein concentrate changes the texture of breads, making dough coarser and more compact.

Moreover, the inclusion of tilapia meal in roll led to a reduction in $\mathrm{pH}$ (Table 4), which varied between 6.04 in the control roll and 5.89; 5.94 and 5.89 for 5, 10 and 15\% inclusion, respectively. However, this $\mathrm{pH}$ remained within the expected range for bread (Buddrick et al., 2014).

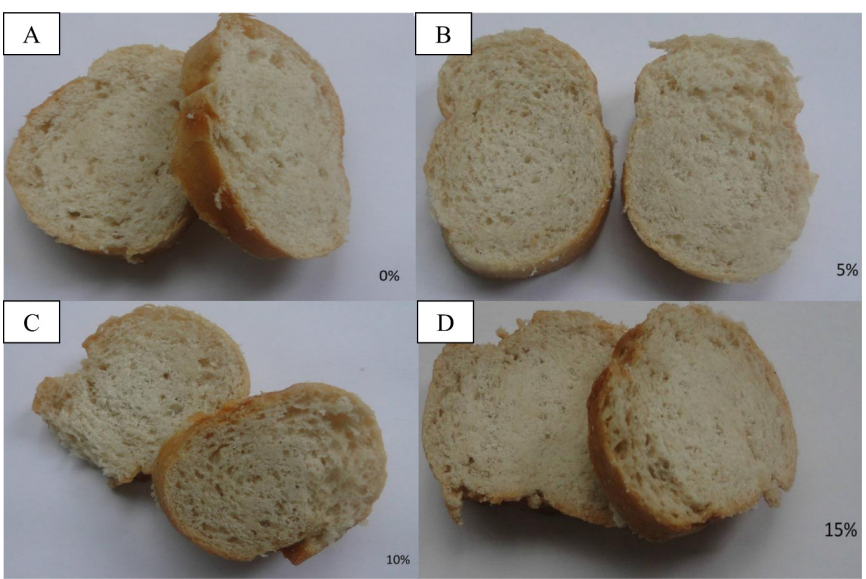

Figure 1. Roll with (A) 0\%; (B) 5\%; (C) 10\% and (D) 15\% inclusion of Nile tilapia meal.
Regarding the results of color of rolls with addition of Nile tilapia meal (Table 4), it can be seen that the lightness decreased linearly $(\mathrm{P}<0.0001)$ with increasing levels of addition of tilapia meal. The chroma $b^{*}$ (yellow-blue component) showed a linear increase ( $\mathrm{P}=0.0002)$, from 17.30 for the level 0 to 19.03 for $15 \%$ inclusion. This demonstrates that the rolls became darker with the increase in inclusion levels of fishmeal, and this may occur by the color of the meal.

The sensory profile of roll (Table 5) clearly showed that the increase in fishmeal inclusion level caused a decrease in acceptance of the rolls, once there was a negative linear effect $(\mathrm{P}<0.01)$ for all properties.

For the acceptability index, the control roll averaged $85.24 \%$, and this value decreased linearly to $70.57 \%$ in roll with $15 \%$ inclusion of fishmeal. This reduction in acceptance may be related to increased firmness of rolls, as well as changes in color due to the inclusion of tilapia meal, as seen in the instrumental color analysis. Despite the decrease in acceptance of the roll containing fishmeal, the lower observed value (70.57\%) can still be considered good, since Dutcosky (2011) recommends a minimum acceptance of $70 \%$ for the product is well accepted. Furthermore, scores above 6 (like slightly) indicate that the tasters had a positive acceptance of the product, regardless of treatment.

Breads included with 0, 5, 10, 15 and $20 \%$ tilapia protein concentrate developed by Adeleke \& Odedeji (2010) had the same sensory acceptance up to $15 \%$ inclusion, and only the level of $20 \%$ protein concentrate resulted in lower preference. Also, Centenaro et al. (2007) reported an increasing rejection by panelists according to increased concentration of fishmeal in the formulation of bread, due to changes in flavor.

Table 4. Colorimetry of of rolls with different levels of inclusion of Nile tilapia meal.

\begin{tabular}{|c|c|c|c|c|c|}
\hline & \multicolumn{4}{|c|}{ Inclusion levels } & \multirow{2}{*}{ P-value } \\
\hline & $0 \%$ & $5 \%$ & $10 \%$ & $15 \%$ & \\
\hline $\mathrm{L}^{*}$ & $76.78 \pm 0.12$ & $76.40 \pm 0.28$ & $76.11 \pm 0.18$ & $74.47 \pm 0.25$ & $<0.0001^{\circ}$ \\
\hline$a^{*}$ & $6.39 \pm 0.08$ & $6.48 \pm 0.12$ & $6.15 \pm 0.08$ & $6.43 \pm 0.14$ & 0.6983 \\
\hline $\mathrm{b}^{*}$ & $17.30 \pm 0.23$ & $18.19 \pm 0.18$ & $17.93 \pm 0.19$ & $19.03 \pm 0.28$ & $0.0002^{\mathrm{t}}$ \\
\hline
\end{tabular}

${ }^{a} \mathrm{y}=-0.1443 \mathrm{x}+77.0235 \mathrm{R}^{2}=0.63 ;{ }^{b} \mathrm{y}=0.0991 \mathrm{x}+17.3705 \mathrm{R}^{2}=0.45$. Values presented as mean \pm standard error of the mean. $\mathrm{L}^{*}=$ lightness; $\mathrm{a}^{*}=$ red-green component; $\mathrm{b}^{*}=\mathrm{yellow}-\mathrm{blue}$ component.

Table 5. Sensory profile, acceptability index, purchase intent of of rolls with different levels of inclusion of Nile tilapia meal.

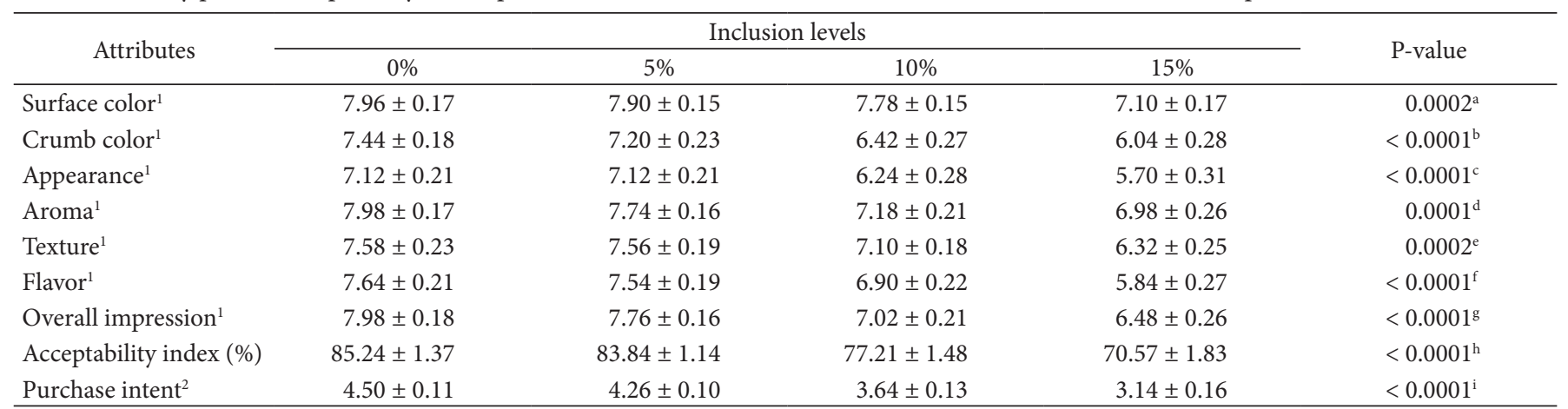

${ }^{1}$ Hedonic scale from 1 (dislike extremely) to 9 (like extremely); ${ }^{2}$ Hedonic scale from 1 (definitely will not buy) to 5 (definitely will buy). ${ }^{\mathrm{a}} \mathrm{y}=-5.4 \mathrm{x}+8.09 \mathrm{R}{ }^{2}=0.77 ; \mathrm{y}^{\mathrm{y}}=-9.96 \mathrm{x}+7.522$ $R^{2}=0.96 ;{ }^{c} y=-10.28 x+7.316 R^{2}=0.89 ;{ }^{d} y=-7.12 x+8.004 R^{2}=0.96 ;{ }^{e} y=-8.48 x+7.776 R^{2}=0.86 ;{ }^{f} y=-12.08 x+7.886 R^{2}=0.88 ;{ }^{g} y=-10.48 x+8.096 R^{2}=0.96 ;{ }^{h} y=-101.28 x+86.811$ $\mathrm{R}^{2}=0.93 ;{ }^{\mathrm{i}} \mathrm{y}=-9.4 \mathrm{x}+4.59 \mathrm{R}^{2}=0.97$. Values presented as mean \pm standard error of the mean. 
The sensory characteristics most altered by the inclusion of $15 \%$ fishmeal in the roll were appearance (5.70) and flavor (5.84), indicating a lower acceptance for these characteristics, since the scores were between 5 (neither like nor dislike) and 6 (like slightly). The lowest score for purchase intent (3.14) was also observed for $15 \%$ inclusion, indicating indecision of tasters as too the purchase of this bread (score $3=$ maybe buy/maybe not buy).

As rolls are accepted and consumed by people of any age and social class, the products developed in this work represent a practical and healthy option that can be used to improve the profile of protein, mineral and fatty acids taken daily.

\section{Conclusion}

The addition of 5 to $15 \%$ Nile tilapia meal to roll has proven to be effective to increase the content of protein and mineral matter of the roll, besides reducing carbohydrate content. The increase in the level of inclusion of Nile tilapia meal increases the firmness of roll and decreases its volume and reduces the acceptance of the product. Therefore, it is recommended to use up to $10 \%$ of tilapia meal in roll.

\section{References}

Adeleke, R. O., \& Odedeji, J. O. (2010). Acceptability studies on bread fortified with Tilapia fish flour. Pakistan Journal of Nutrition, 9(6), 531-534. http://dx.doi.org/10.3923/pjn.2010.531.534.

Americam Pubblic Health Association - APHA. (1992). Compendium of methods for the microbiological examination of foods (3rd ed.). Washington: APHA.

Angioloni, A., \& Collar, C. (2011). Nutritional and functional added value of oat, Kamut, spelt, rye and buckwheat versus common wheat in breadmaking. Journal of the Science of Food and Agriculture, 91(7), 1283-1292. PMid:21337578. http://dx.doi.org/10.1002/jsfa.4314.

Association of Official Analytical Chemists - AOAC. (2005). Official methods of analysis of the Association of Official Analytical Chemists (18th ed.). Gaithersburg: AOAC.

Besbes, E., Jury, V., Monteau, J. Y., \& Bail, A. (2014). Effect of baking conditions and storage with crust on the moisture profile, local textural properties and staling kinetics of pan bread. LebensmittelWissenschaft + Technologie, 58(2), 658-666. http://dx.doi.org/10.1016/j. lwt.2014.02.037.

Bligh, E. G., \& Dyer, W. J. (1959). A rapid method of total lipid extraction and purification. Canadian Journal of Biochemistry and Physiology, 37(8), 911-917. PMid:13671378. http://dx.doi.org/10.1139/o59-099.

Bonafé, E. G., Morais, D. R. D., Figueiredo, L. C. D., Souza, N. E., Santos, O. O., Claus, T., \& Visentainer, J. V. (2013). Incorporation and profile of fatty acids in tilapia fillets (Oreochromis niloticus) fed with tung oil. Food Science and Technology (Campinas), 33, 47-51. http://dx.doi.org/10.1590/S0101-20612013000500008.

Brasil. Agência Nacional de Vigilância Sanitária. (2001). Regulamento técnico sobre padrões microbiológicos para alimentos. Diário Oficial [da] República Federativa do Brasil, Brasília.

Buddrick, O., Jones, O. A., Cornell, H. J., \& Small, D. M. (2014). The influence of fermentation processes and cereal grains in wholegrain bread on reducing phytate content. Journal of Cereal Science, 59(1), 3-8. http://dx.doi.org/10.1016/j.jcs.2013.11.006.
Carr, L. G., \& Tadini, C. C. (2003). Influence of yeast and vegetable shortening on physical and texture parameters of frozen part baked French bread. Lebensmittel-Wissenschaft + Technologie, 36(6), 609614. http://dx.doi.org/10.1016/S0023-6438(03)00079-3.

Carr, L. G., Rodas, M. A., Della Torre, J. C., \& Tadini, C. C. (2006). Physical, textural and sensory characteristics of 7-day frozen partbaked French bread. Lebensmittel-Wissenschaft + Technologie, 39(5), 540-547. http://dx.doi.org/10.1016/j.lwt.2005.03.012.

Centenaro, G. S., Feddern, V., Bonow, E. T., \& Salas-Mellado, M. (2007). Enriquecimento de pão com proteínas de pescado. Ciência e Tecnologia de Alimentos, 27(3), 663-668. http://dx.doi.org/10.1590/ S0101-20612007000300036.

Cho, J. H., \& Kim, I. H. (2011). Fishmeal nutritive value. Journal of Animal Physiology and Animal Nutrition, 95(6), 685-692. PMid:21198959. http://dx.doi.org/10.1111/j.1439-0396.2010.01109.x.

Collar, C. (2015). Bread and bakery products. In M. Guardia \& S. Garrigues (Eds.), Handbook of Mineral Elements in Food (pp. 559572). Chichester: John Wiley \& Sons.

Dhinda, F., Lakshmi, A. J., Prakash, J., \& Dasappa, I. (2012). Effect of ingredients on rheological, nutritional and quality characteristics of high protein, high fibre and low carbohydrate bread. Food and Bioprocess Technology, 5(8), 2998-3006. http://dx.doi.org/10.1007/ s11947-011-0752-y.

Dutcosky, S. D. (2011). Análise sensorial de alimentos (3rd ed.). Curitiba: Champagnat.

El-Dash, A. A., Camargo, C. O., \& Diaz, N. M.(1982). Fundamentos da tecnologia de panificação (243 p.). São Paulo: Secretaria da Indústria, Comércio e Tecnologia do Estado de São Paulo.

El-Dash, A. A., Mazzari, M. R., \& Germani, R. (1994). Tecnologia de farinhas mistas. Uso de farinha mista de trigo e milho na produção de pães. EMBRAPA-CTAA, 1, 42-88.

Esteller, M., Pitombo, R., \& Lannes, S. C. S. (2005). Effect of freeze-dried gluten addition on texture of hamburger buns. Journal of Cereal Science, 41(1), 19-21. http://dx.doi.org/10.1016/j.jcs.2004.08.013.

Goes, E. S. R., Souza, M. L. R., Michka, J. M. G., Kimura, K. S., Lara, J. A. F., Delbem, A. C. B., \& Gasparino, E. (2016). Fresh pasta enrichment with protein concentrate of tilapia: nutritional and sensory characteristics. Food Science and Technology (Campinas), 36(1), 76-82. http://dx.doi.org/10.1590/1678-457X.0020.

Hussain, I., Akhtar, N., \& Hussain, S. (2007). Evaluation of weaning food khitchri incorporated with different levels of fish protein concentrate. Animal Plant Sciences, 17, 12-17.

Ibrahim, S. M. (2009). Evaluation of production and quality of saltbiscuits supplemented with fish protein concentrate. World Journal of Dairy \& Food Sciences, 4, 28-31.

Justen, A. P., Souza, M. L. R., Monteiro, A. R., Mikcha, J. M., Gasparino, E., Delbem, Á. B., Carvalho, M. R. B., Del Vesco, A. P. (2016). Preparation of extruded snacks with flavored flour obtained from the carcasses of Nile tilapia: physicochemical, sensory, and microbiological analysis. Journal of Aquatic Food Product Technology, 258-266.

Marik, P. E., \& Varon, J. (2009). Omega-3 dietary supplements and the risk of cardiovascular events: a Systematic Review. Clinical Cardiology, 32(7), 365-372. PMid:19609891. http://dx.doi.org/10.1002/clc.20604.

Sidwell, V. D., \& Hammerle, O. A. (1970). Changes in physical and sensory characteristics of doughs and of bread containing various amounts of fish protein concentrate and lysine. Cereal Chemistry, 47, 739-745.

Souza, N. E., Stevanato, F. B., Garcia, E. E., Visentainer, J. E., Zara, R. F., \& Visentainer, J. V. (2008). Supplemental dietary flaxseed oil affects both neutral and phospholipid fatty acids in cultured tilapia. 
European Journal of Lipid Science and Technology, 110(8), 707-713. http://dx.doi.org/10.1002/ejlt.200700245.

Strànsky, K., Jursík, T., \& Vitek, A. (1997). Standard equivalent chain length values of monoenic and polyenic methylene interrupted fatty acids. Journal of High Resolution Chromatography, 20(3), 143-158. http://dx.doi.org/10.1002/jhrc.1240200305.

Tacon, A. G., \& Metian, M. (2013). Fish matters: Importance of aquatic foods in human nutrition and global food supply. Reviews in Fisheries Science, 21(1), 22-38. http://dx.doi.org/10.1080/10641 262.2012.753405.

Van Steertegem, B., Pareyt, B., Slade, L., Levine, H., Brijs, K., \& Delcour, J. A. (2013). Impact of heat treatment on wheat flour Solvent Retention
Capacity (SRC) profiles. Cereal Chemistry, 90(6), 608-610. http:// dx.doi.org/10.1094/CCHEM-04-13-0069-N.

Verheyen, C., Albrecht, A., Elgeti, D., Jekle, M., \& Becker, T. (2015). Impact of gas formation kinetics on dough development and bread quality. Food Research International, 76(Pt 3), 860-866. PMid:28455072. http://dx.doi.org/10.1016/j.foodres.2015.08.013.

Walker, C. G., Jebb, S. A., \& Calder, P. C. (2013). Stearidonic acid as a supplemental source of $\omega-3$ polyunsaturated fatty acids to enhance status for improved human health. Nutrition (Burbank, Los Angeles County, Calif.), 29(2), 363-369. PMid:23102888. http://dx.doi. org/10.1016/j.nut.2012.06.003. 